\title{
Collaborative Writing in EFL Classroom: Comparison on Group, Pair, and Individual Writing Activities in Argumentative Tasks
}
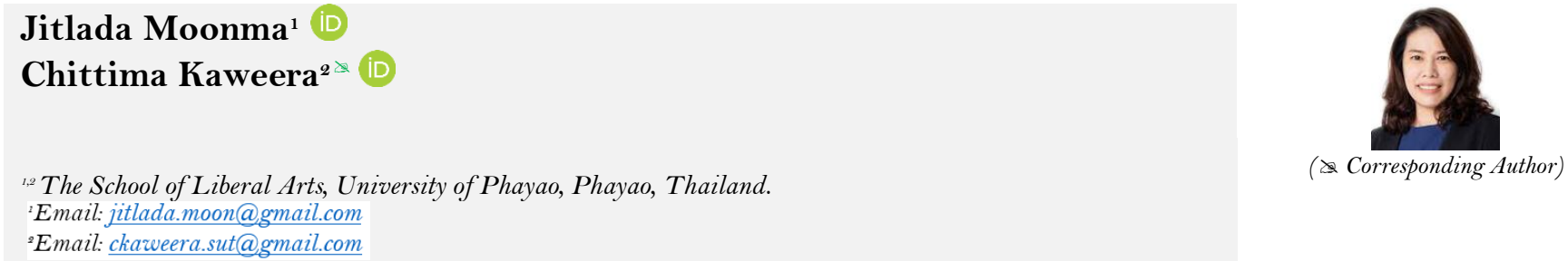

Abstract

This study focused on comparing the effects on 32 students' argumentative writing qualities when they worked alone or collaborated in pairs and groups and explored the students' opinions towards critical thinking across different writing activities. The 32 students were divided into groups of four $(n=8)$, pairs $(n=16)$ and individuals $(n=32)$. Their papers were rated in terms of content, language use, and organization by three raters. The research employed argumentative writing rubrics, semi-structured interview, and observation. From the total of 15 points, the novice learners gained the highest scores when writing in groups $(\overline{\mathrm{X}}=11.22)$, followed by pairs $(\overline{\mathrm{X}}$ $=10.19)$ and individuals $(\overline{\mathrm{X}}=8.98)$. The intermediate learners also gained the highest scores in group work $(\overline{\mathrm{X}}=11.50)$, followed by pairs $(\overline{\mathrm{X}}=10.32)$, and individual work $(\overline{\mathrm{X}}=9.04)$, respectively. Similar to the advanced level, they had the highest scores when working in groups $(\overline{\mathrm{X}}$ $=11.95)$, followed by pairs $(\overline{\mathrm{X}}=10.45)$, and individuals $(\overline{\mathrm{X}}=9.45)$. The findings indicated that group work led to the highest scores in all proficiency levels and in groups, the students' critical thinking improved regarding analyzing, evaluating and creating information when they brainstormed, shared and discussed all information. In pairs, the students also demonstrated that their critical thinking developed but only in analyzing from sharing information with a partner. In individuals, all proficiency levels reported that critical thinking was not developed as no interaction with peers.

Keywords: Collaborative writing, Group work, Pair work, Individual work, Argumentative writing, Writing activities.

Citation | Jitlada Moonma; Chittima Kaweera (2021). Collaborative Writing in EFL Classroom: Comparison on Group, Pair, and Individual Writing Activities in Argumentative Tasks. Asian Journal of Education and Training, 7(3): 179-188.

History:

Received: 26 May 2021

Revised: 21 June 2021

Accepted: 13 July 2021

Published: 24 August 2021

Licensed: This work is licensed under a Creative Commons Attribution 3.0 License (oc)

Publisher: Asian Online Journal Publishing Group
Acknowledgement: Both authors contributed to the conception and design of the study.

Funding: The research project is funded by Unit of Exellence, University of Phayao.

Competing Interests: The authors declare that they have no conflict of

interests.
Transparency: The authors confirm that the manuscript is an honest, Transparency: The authors confirm that the manuscript is an honest,
accurate, and transparent account of the study was reported; that no vital accurate, and transparent account of the study was reported; that no vital
features of the study have been omitted; and that any discrepancies from the study as planned have been explained.

Ethical: This study follows all ethical practices during writing.

\section{Contents}

1. Introduction

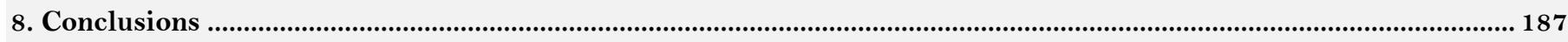

References.. 


\section{Contribution of this paper to the literature}

This study contributes to existing literature by comparing the effects on 32 students' argumentative writing qualities when they worked alone or collaborated in pairs and groups and explored the students' opinions towards critical thinking across different writing activities.

\section{Introduction}

Previous studies have illustrated that collaborative writing $(\mathrm{CW})$ activities are beneficial activities as they enhance language learning in the language classroom ( $\mathrm{Li} \& \mathrm{Zhu}, 2017$ ). Furthermore, learning to write argumentatively is an essential skill for students in a university context (Wu \& Allison, 2005). Nevertheless, collaborative writing places many challenges since students come from different backgrounds where such analytical writing, and its associated thinking, is not common. In fact, writing argumentatively is "one of the greatest challenges many English language learners (ELLs) are likely to face” (Hirvela, 2013). Pairs and small group works remain one of the most common activity grouping in communicative second language (L2) classrooms (Dobao, 2012). However, in regular university classrooms, group work has a tendency to be still restricted to brainstorming techniques and the peer review processes. In the past few decades, various studies have paid attention to the usefulness of collaborative writing activities, in which students are assigned to write in pairs and groups throughout all phases of the writing process (Kaweera, Yawiloeng, \& Tachom, 2019; Zhang, 2019).

Currently, collaborative writing has become common in many language classroom contexts in the past few decades (Zhang, 2018) and is recognized as one of the fruitful instruments in writing processes (Shehadeh, 2011). In the past, much of the early research in the L2 classroom has investigated collaborative oral activities such as decision-making, exchanging information, raising consciousness, and picture-narration tasks. Recently researchers began to pay attention increasingly to collaborative activities during the writing process ( $\mathrm{Li} \& \mathrm{Kim}, 2016$; Li \& Zhu, 2017; Neumann \& McDonough, 2015; Storch, 2013; Zhang, 2019).

Furthermore, Vygotsky (1978) emphasizes the crucial importance of community in the generation of knowledge since, according to him, learners need to learn from each other and to transfer what they know. Socialisation with a more effective member of the group improved cognitive development. The more skilled member expands their peers beyond their level of competence towards their prospective level of development by providing their peers with the proper level of assistance (Storch, 2005). Nevertheless, most existing research has examined only intermediate or advanced level learners (Chen, Elchert, \& Garmager, 2018; Chen \& Yu, 2019; Dobao \& Blum, 2013; Zhang, 2018). They did not conduct the research across the students' proficiency levels (Dobao, 2012). The results of the research mentioned earlier cannot be generalized across "proficiency levels" (Chen \& Yu, 2019; McDonough \& De Vleeschauwer, 2019). Therefore, the present study took into account all levels of English language proficiency (novice, intermediate, and advanced) when performing different collaborative writing tasks.

\section{Literature Review}

\subsection{Collaborative Writing Theoretical and Pedagogical Perspectives}

CW was originally defined by Vygotsky's Sociocultural Theory (Vygotsky, 1978) as an activity in which writers co-construct and share ideas in order to produce a single writing paper (McDonough, Crawford, \& De Vleeschauwer, 2016). Similar to Storch (2005), the use of CW in the L2 classroom is reinforced by the perspectives of a Social Constructivist Theory of learning, which is identified in Vygotsky (1978).

Focusing on the theoretical side, Donato (1994) states that while learners communicate with each other in meaningful ways, they engage in meaning-negotiation about the second language. Furthermore, according to Roberson (2014), peer response is supported by the communicative language teaching approach which puts authentic interactions between the learners as well.

Regarding the pedagogical boundary, various researchers have explored the advantages of collaboration in L2 learning. Swain (2000), Swain and Lapkin (2001) suggests that CW activities encourage writers to reflect on their language usage and work jointly in the solution of their language problems. McDonough (2004) states that relating with each other during pair and group activities decreased the students' anxiety, and increased the students' self-confidence (p.208). McDonough. et al. (2016) also indicates a relationship between the prewriting tasks which elicited 'student talk' about content and organization. Furthermore, Dunkel-Schetter and Bennett (1990) realizes this activity as a chance for learners to work together and learn from each other. The learners assist their peers without feeling reluctance. As a result, this activity feature would be conducive to better learning.

To sum up, CW activities have some benefits: firstly, fostering students to reflect on their language use and work collaboratively through their language-related problems; secondly, letting them feel more self-confident when working with partners during pairs and groups compared to during class talking; thirdly, eliciting student discussion about content and organization; finally, decreasing feelings of embarrassment as collaborative writing activities let them interact and help each other. Consequently, these collaborative activities are believed to help learners without them feeling embarrassed and would lead to better language learning and critical thinking skills.

\subsection{Related Research on Argumentative Writing in Collaborative Writing}

In conducting collaborative activity research, writing skills are the essential skill set that is the most interesting, as writing skills require conscious attention and sometimes have to be performed step by step. Writing is frequently considered to be the most complex skill of learning a language. Therefore, writing in English as a foreign language (EFL) classes are complex for both teachers and students because there are many features to cover (Ghufron \& Hawa, 2018). Raimes (1983) mentions those features are grammatical rules, content, the writers' process, audience, purpose, word choice, organization, and mechanics. For worthwhile writing, the writer is required to implement a large number of formal features in order to assist readers to grasp the intended meaning. Failure to implement these aspects correctly generates obscurity, ellipsis and ambiguity in some writings (Ghufron \& Hawa, 2018). 
Regarding argumentative writing, the students are required to investigate a topic, collect, generate, and evaluate the evidence and establish a position on the topic in a concise manner. Furthermore, making a good argument is required. Consequently, Kuhn (1991) claimed that developing an argument is an essential thinking skill to formulate ideas and solve language problems. In this study, CW activities were implemented in argumentative writing in order to enhance students' argumentative writing ability as it may be a technique that encourages a pooling of knowledge about language, brainstorming, discussing, and solving problems when they write collaboratively. However, compared to other writing types in the educational field, very few empirical studies have paid particular attention to training students to write argumentatively (Lukomskaya, 2015) as the argumentative paragraph is commonly assigned as sophisticated writing and relates to prolonged, detailed research (Ka-kan-dee \& Kaur, 2015).

Regarding writing ability, CW increased argumentative writing skill. According to Ghufron and Hawa (2018), the study aimed to find out whether or not teaching using CW techniques was a more effective method in teaching how to write an argumentative paragraph. This experimental research was carried out in IKIP PGRI Bojonegoro. The population was 126 students who were the fourth semester students of the English Education Department. The experimental group where each group consisted of 42 students was treated by using CW techniques, whereas the control group was treated by using Direct Instruction. The findings illustrated that CW techniques can improve argumentative writing ability in the experimental group.

Similar to Morris et al. (2018), 5th grade students in two urban school districts completed an integrated unit on wolves. Classes received either collaborative group work (CG) or direct instruction (DI). The results indicated that an analysis of the reasoning in classroom discussion illustrated that CG students more often implemented connective and contrastive words and the performative verb phrases I think and I know than DI students. Analysis of written arguments about a controversial question raised by the unit indicates that, compared to DI students, CG students include more rational connective, contrastive, and performative verbs, produce fewer unsophisticated arguments, and more frequently ask linguistic questions.

In accordance with the study of Ka-kan-dee and Kaur (2015) a semi-structured interview and a stimulated recall interview was implemented to collect elaborated information from two Thai EFL lecturers about the challenges in teaching argumentation, with the teaching strategies implemented to assist improving their students' argumentative skills. The study showed that students encounter problems due to insufficient knowledge of grammatical rules, lexis and argumentation. Moreover, the students confronted difficulties in organizing ideas and producing evidence to write a well-organized essay. Their study also indicates that the students' weaknesses were the main obstacles for Thai EFL students to compose an argumentative paragraph. In addition, Thai university students had less experience with argumentation as this kind of writing was not taught to them in the past while they were at school. Consequently, they implemented different inputs and activities to integrate in teaching argumentative writing. The activities included pair and group, explanation, illustration and debate in the classroom in order to improve the university level students' argumentative writing skills. The results suggested that EFL students can establish proficient social and effective writing argumentative paragraphs using proficient collaboration, when receiving close guidelines from their teachers in the writing class.

Furthermore, regarding learners' writing accuracy, CW fostered students' argumentative improved their writing accuracy as well. According to Jafari and Ansari (2012), it focused on the outcomes of group work on Iranian EFL learners' writing accuracy in writing argumentatively. Over a month, sixty Iranian EFL learners were divided into two groups. The experimental group wrote collaboratively whereas the control group wrote individually. Both groups participated in writing two argumentative essays. The participants wrote on the same topics and genre (using argumentative writing). The results indicated that the students in the CW group performed better than the students in the control group; therefore, emphasizing the significant role of collaboration in L2 writing, especially in writing accuracy.

In summary, researchers and educators are increasingly conscious of both the writing and teaching improvement for university learners. Consequently, it is beneficial for EFL teachers in Thailand to implement various collaboration activities such as pair or group activities in order to develop effective instructions which enable students to enhance their argumentative writing skill. Furthermore, the results of previous research asserted that CW teaching techniques played an essential role in the students' argumentative writing capacity. This means that writing capacity depends on teaching techniques and that $\mathrm{CW}$ technique is effective for the students. From these studies, argumentative writing ability was focused when doing CW activities. It can be assumed that CW techniques affected students' writing ability (Ghufron \& Hawa, 2018). It is a genre that can enhance the students' argumentative writing ability which is highly required at university level and academic context (Ka-kan-dee \& Kaur, 2015).

\subsection{Critical Thinking Skills}

Apart from the benefits for teaching and learning, collaborative activities have been studied in a number of previous research on critical thinking skills which are regarded as a highly essential educational purpose in many institutions around the world (Behar-Horenstein \& Niu, 2011). In the educational field, critical thinking is implemented with the concept of higher-order thinking, from Bloom's taxonomy (Anderson, 2001). Regarding Revised Bloom's taxonomy in 2001, cognitive skills can be grouped according to their level of complexity. In this sense, higher-order thinking skills therefore correspond to levels of analyzing, evaluating, and creating.

\subsection{Flaws on Collaborative Writing Research in EFL Classroom}

According to Dobao (2012), CW was a powerful activity that encouraged peer learning, cooperation, active engagement, and critical thinking skills, towards an end result. It was meaningful engagement and shared decision making between members of a group using a common set of tools. The practice of CW has fairly recently (in comparison to other, more traditional techniques) entered classrooms in response to the need of addressing the issues of negotiating, combining ideas, and structuring arguments in a written form Dobao (2012). Moreover, CW activities have received increasing attention in the past decades (Zhang, 2018). However, considering the drawbacks of CW research, there are still some issues left. 
Firstly, as argumentative writing skill is required at a higher level in university where making a good argument is necessary (Wu \& Allison, 2005). Furthermore, argumentative writing is one of the greatest challenges that many English language learners are likely to encounter (Hirvela, 2013). Kuhn (1991) considers writing argumentatively to be a higher-order thinking skill important to idea formulation, problem-solving, and good judgement. Moreover, the students encounter problems since learners have insufficient knowledge of syntax, lexical features and argumentative features. The students encounter difficulties in organizing ideas and assessing evidence to write a well-organized essay (Ka-kan-dee \& Kaur, 2015). However, compared to other topics in the educational field, very few empirical studies have focused especially on training students to write argumentatively and the number of research projects conducted in argumentative CW skills are still limited (Lukomskaya, 2015). On the other hand, there have been a number of studies in CW research focused exclusively on one task: persuasive, comparison, and problem solving topics (Chen \& Yu, 2019); paragraph-level writing (McDonough \& De Vleeschauwer, 2019); problem-solution paragraph (2018); essay writing (Hanjani \& Li, 2014) and expository essays (Kaweera et al., 2019).

Secondly, collaboration with various English proficiency levels should be examined. The current study focused on providing a broader collaborative method perspective. It is noted that, since a number of studies focus on intermediate levels and advanced levels, the findings obtained cannot be inferred across all proficiency levels (Chen \& Yu, 2019; Dobao, 2012; McDonough \& De Vleeschauwer, 2019). In order to provide a broader perspective in different proficiency levels, this study placed students in novice, intermediate, and advanced levels. Another issue is that critical thinking is also crucial to encourage students to learn. In the current era, it is one of the essential skills that need to be elicited as well.

Finally, regarding the aspect of critical thinking, a few studies explore critical thinking skills in the CW processes. A number of studies investigated perspective and satisfaction on collaborative learning (Chen \& Yu, 2019; Kaweera, 2013; Kaweera et al., 2019; Liu, Shaw, Gu, \& Li, 2018; McDonough \& De Vleeschauwer, 2019). According to Liu et al. (2018) there were not many studies investigating critical thinking skills during the CW process. Most of them investigated students' perspectives, attitudes, and satisfaction when they engaged in the CW process. One of the four skills investigated while students were participating in the writing process was thinking skill which was too broad to identify what types of thinking skill occurred. Though, it is crucial and interesting to investigate critical thinking which is one of the skills needed in the 21 st century.

To sum up, in an attempt to fill in these gaps in the existing literature, the current study investigated the influence of collaborative (pairs and groups of four) and individual writing on students' argumentative writing ability in all proficiency levels especially in an English as a foreign language (EFL) environment.

\section{Research Questions}

The main purpose of the present study is to analyze the effects of the students' argumentative writing quality across different writing activities and explore the students' attitudes towards CW activities and the strategies which the students used to develop their critical thinking skills in CW activities.

1. What are the effects of group, pair and individual work on the students' argumentative writing abilities using $\mathrm{CW}$ activities in all levels of the students?

2. What are the attitudes towards the uses of CW across different writing activities (group, pair, and individual work) and how do the students use CW to develop their critical thinking skills?

\section{Scope of the Study}

The study was carried out over a period of three weeks and utilized a non-probability sampling which did not relate to random sampling. The 32 Thai EFL university students registered in the Writing II were selected to engage in this study. This study addressed the students' argumentative writing quality across different writing activities. The three activities utilized in the present study were a group of four CW activities; pair writing activities; and individual writing activities. Furthermore, this study intended to explore the students' attitudes towards critical thinking skills practicing across three different writing activities and how the students use CW to develop their critical thinking skills.

\section{Methodology}

\subsection{Participants}

The study was administered to second-year English major students studying English as a foreign language at a northern Thai university. 32 students participated in this study (13 males and 19 females), and their ages ranged from 19-21, with an average of 20. They were all non-native English speakers. All participants were registered in the same second-year Writing II course after they had completed the Writing I course. Most of them had studied English in schools for more than 10 years before entering university. Based on their grades during the Writing I course, they were placed in three different proficiency levels: advanced, intermediate, and novice based on their grades in the Writing I course. Table 1 shows the student numbers in each level.

Table-1. Students' different levels of English proficiency.

\begin{tabular}{c|c|c|c|c}
\hline English Proficiency Levels & Novice & Intermediate & Advanced & Total \\
\hline Numbers of Students & 18 & 8 & 6 & 32 \\
\hline Percentage & 56.25 & 25 & 18.75 & 100 \\
\hline
\end{tabular}

\subsection{Writing Tasks}

The writing tasks were designed and given to the students throughout the course. All 32 students experienced the same treatment. They were taught the same syllabus by the same teacher (researcher). The syllabus consisted of 17 weeks including midterm and final examination as well as teaching and evaluation materials.

Six lessons were designed based on collaborative learning. There were four hours a week lasting 240 minutes in each. The lesson plans were given to the advisor and experts for checking, proofing, and editing the content. 
Then, the lesson plans were edited and implemented with second-year English major students in Writing II (1551116) course using CW activities (adapted from White and Arndt (1991)) including eight steps as follows:

1) Overview step (20 minutes): the students were taught collaborative and individual writing by the teacher. It began with the teacher informing the students about the general concepts of group, pair, and individual writing. Students were allowed to ask questions before going onto to the next step.

2) Studying step (30 minutes): the teacher provided the short text model and taught the grammatical structure of argumentative writing such as arguing for or against a controversial issue of students' interest. Firstly, the teacher introduced the model of an argumentative paragraph and allowed the students to consider the writing style in which this genre and the language of arguments occurred, the purpose of argumentation and the type of the audience for the model of argumentative paragraph. Next, students were presented with the argumentative patterns.

3) Pre-writing step (30 minutes): the students planned the structure of their own paragraph or structured outline and generated ideas and put ideas in the outline for an appropriate argumentative topic. Then, they brainstormed to research an argumentative topic using outlining, listing, freewriting, brainstorming ideas and then organized all information.

4) Drafting step (40 minutes): the students wrote their first rough draft based on the structure outline in groups of four (week 12), pairs (week 13) and individuals (week 14). The teacher was available to help the students, or be consulted about the writing process. For the first draft, they focused on introduction, body and conclusion.

5) Revising step (40 minutes): the students revised the first rough draft paying attention to vocabulary, content and organization. Rewriting was aimed at the changes identified in the revision stage in order to produce the second draft.

6) Rewriting step (30 minutes): the students rewrote the draft including the changes identified in the revision stage in order to produce the third draft. The model of writing tasks

7) Proofreading step (30 minutes): once students finished the third draft, they submitted their paper to the teacher. Then, they were taught to revise their draft at the revision stage. To revise their draft, the students analyzed the final draft in accordance with spelling, grammar, punctuation and mechanical errors in order to produce the fourth draft.

8) Publishing step (20 minutes): the students wrote the completed argumentative paragraph and submitted it to the teacher (group work of four students, pair work, and individual work). The group work submitted one piece of paper, the same as pair work. In contrast to individual work, each student submitted his or her own writing paper to the teacher. The writing task model was shown in Figure 1.

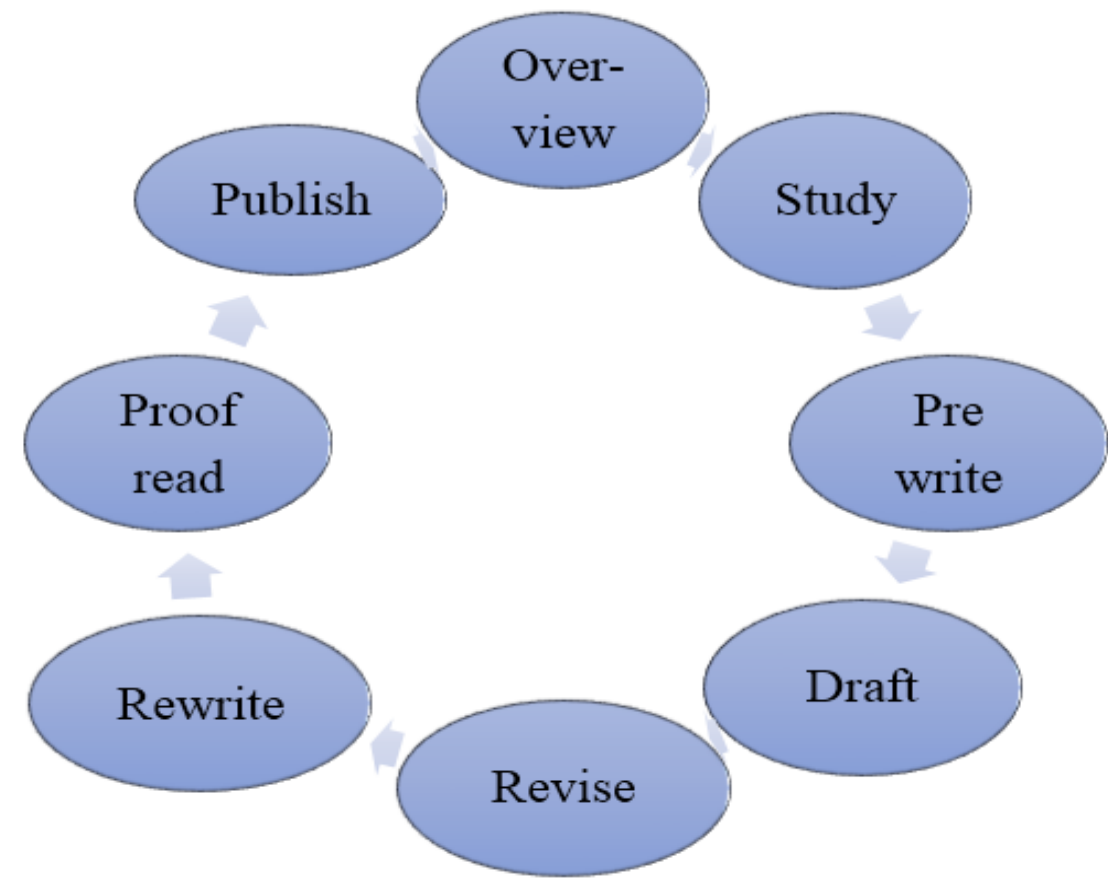

Figure-1. Model of the writing activity adapted from White and Arndt (1991).

In this study, the students were allowed to communicate in their first language (Thai) instead of the target language (English). As based on Shehadeh (2011) the student would feel more confident to participate in writing and moreover, using English might impede their vocabulary and their imagination or original ideas when being assigned to negotiate in English.

\subsection{Data Collection and Analysis}

The data was divided into three categories: examining the effects of using the CW activities (groups of four, pairs, and individual work) to enhance the quality of the students' argumentative writing quality and to explore the students' attitudes towards critical thinking skills in CW activities (groups and pairs).

The quantitative data was used to assess the students' argumentative writing quality in three different writing activities using criteria adapted from Zhang (2019). Qualitative data was collected from the six students' attitudes across all proficiency levels ( 2 novices, 2 intermediates and 2 advanced levels) towards critical thinking skills (groups of four and pairs). This involved using semi-structured interviews and observed 4 groups during their writing activities in order to investigate the students' learning levels in CW using Bloom's Taxonomy. 


\subsection{Research Instruments}

For the writing tasks, the five argumentative paragraphs were examined to assess the students' argumentative writing ability. The scoring criteria was adapted from Zhang (2019) to evaluate 3 significant criteria (content, language use, and organization). Each paragraph had a total score of 15 . The students' scores were calculated to find the percentage compared to the required score and to rate their argumentative writing ability in each task. Furthermore, the scores of five argumentative writing tasks of each student were calculated in order to find the total scores. The scoring adapted from Zhang (2019) which contained certain significant criteria and definitions as follow:

1) Content: Development of content using relevant and suitable examples, facts, and evidence and showing an obvious and consistent stance on the topic.

2) Language use: Demonstrate a variety of syntax, appropriate word choices and idioms and having little lexical and grammatical errors that did not impede the meaning.

3) Organization: Ensure that ideas and transitions were used appropriately and logically connected throughout the paragraph and that the progressions of ideas were coherent.

\subsubsection{Semi-Structured Interview}

The semi-structured interview was implemented to collect the participants' perspectives on practicing critical thinking skills towards CW activities (group and pair work). There was a question which was approved and edited by three experts in English teaching: two Thai teachers and one native speaker. A total of six students were randomly chosen to affiliate in the interview protocol managed separately, two from each of three English proficiency levels (novice, intermediate and advanced). Tape recording and video recording were implemented in each interview session administered in Thai and translated into English and observation was involved during different writing activities. The students were asked the following question:

- What are your attitudes towards critical thinking skills in the individual, pairs, and group writing activities?

\subsubsection{Observation}

The observation of the classroom proved to be useful in the analysis (Paul, 1989; Wiersma, 1995; Woo, 1999). The researcher implemented learning levels of Revised Bloom's Taxonomy (Anderson \& Krathwohl, 2001) to provide the student learning using a six-level classification framework. Bloom's classification could be applied to the observations of the CW activities. The six-tiered classification framework of students' learning represented an organized hierarchy of students' critical thinking processes from the lowest to the highest: gathering knowledge, comprehension, application, analysis, synthesis, and evaluation. The learning levels were summarized and implemented to categorize students' behaviors and conversation during writing activities. Table 2 shows the six categories of revised Bloom's taxonomy.

Table-2. The six categories of revised bloom's taxonomy for teaching and learning processes.

\begin{tabular}{|c|c|c|}
\hline Learning Levels & Definition & Sample cues \\
\hline Creating & $\begin{array}{l}\text { Generating new ideas, products, } \\
\text { or ways of viewing things, } \\
\text { designing, constructing, planning, } \\
\text { producing, inventing. }\end{array}$ & generate, plan, produce \\
\hline Evaluating & $\begin{array}{l}\text { Justifying a decision, checking, } \\
\text { hypothesizing, critiquing, } \\
\text { experimenting, judging }\end{array}$ & check, critique, judge \\
\hline Analyzing & $\begin{array}{l}\text { Breaking information into parts } \\
\text { to explore understanding and } \\
\text { relationships, comparing, } \\
\text { organizing, deconstructing, } \\
\text { interrogating, finding }\end{array}$ & Differentiate, organize, attribute \\
\hline Applying & $\begin{array}{l}\text { Using information in another } \\
\text { familiar situation, implementing, } \\
\text { carrying out, using, executing }\end{array}$ & Execute, implement, apply \\
\hline Understanding & $\begin{array}{ll}\text { Explaining ideas } & \text { or concepts, } \\
\text { interpreting, } & \text { summarizing, } \\
\text { paraphrasing, } & \text { classifying, } \\
\text { explaining } & \end{array}$ & $\begin{array}{l}\text { Explain, } \\
\begin{array}{l}\text { interpret, } \\
\text { summarize, } \\
\text { explain, }\end{array}\end{array}$ \\
\hline Remembering & $\begin{array}{l}\text { Recalling information, } \\
\text { recognizing, listing, describing, } \\
\text { retrieving, naming, finding }\end{array}$ & Recall, recognize, write, list, label \\
\hline
\end{tabular}

\section{Results}

The findings of the quantitative and qualitative analyses administered in relation to the two research questions: 1. What are the effects of group, pair and individual work on the students' argumentative writing by using collaborative writing activities?

2. What are the students' attitudes towards critical thinking practicing in $\mathrm{CW}$ activities (group of four and pair) and how did the students implement CW to develop their critical thinking skills?

\subsection{Research Question I}

What are the effects of group, pair and individual work on the students' argumentative writing by using CW activities? 


\subsubsection{The Students' Writing Quality}

Regarding the students' writing quality, this study compared the mean value of argumentative writing quality across different writing activities.

Table-3. Mean score of writing quality.

\begin{tabular}{c|c|c|c|c|c|c|c}
\hline $\begin{array}{c}\text { English } \\
\text { Proficiency }\end{array}$ & $\begin{array}{c}\text { Number of } \\
\text { Students }\end{array}$ & \multicolumn{2}{c|}{ Groups of four $(\mathbf{n}=\mathbf{8})$} & \multicolumn{2}{c|}{ Pairs (n= 16) } & \multicolumn{3}{c}{ Individual (n= 32) } \\
\hline & & $\bar{X}$ & SD & $\bar{X}$ & SD & $\bar{X}$ & SD \\
\hline Novice & 18 & 11.22 & 0.96 & 10.19 & 1.14 & 8.98 & 1.29 \\
\hline Intermediate & 8 & 11.50 & 0.53 & 10.32 & 0.66 & 9.04 & 0.70 \\
\hline Advanced & 6 & 11.95 & 0.80 & 10.45 & 0.78 & 9.45 & 0.78 \\
\hline Total & 32 & 11.35 & 0.92 & 10.27 & 0.96 & 9.08 & 1.07 \\
\hline
\end{tabular}

Based on Table 3, from a total of 15 points, it was shown that overall students in group writing had the highest score $(\bar{X}=11.35)$, followed by pair writing $(\bar{X}=10.27)$ and individual writing $(\bar{X}=9.08)$, respectively.

According to Figure 2, the students in different English proficiency levels obtained divergent scores across different writing activities. The novice students obtained the highest scores when they participated in group work $(\overline{\mathrm{X}}=11.22)$, followed by pair work $(\overline{\mathrm{X}}=10.19)$ and individual work $(\overline{\mathrm{X}}=8.98)$, respectively. This result was the same as in intermediate students who had the highest scores when writing in a group $(\bar{X}=11.50)$, followed by pair work $(\overline{\mathrm{X}}=10.32)$ and individual work $(\overline{\mathrm{X}}=9.04)$, respectively. In advanced groups, they also gained the highest scores when engaging $\mathrm{CW}$ in group of four $(\overline{\mathrm{X}}=11.95)$, followed by pair writing $(\overline{\mathrm{X}}=10.45)$, and individual writing $(\overline{\mathrm{X}}=9.45)$, respectively.

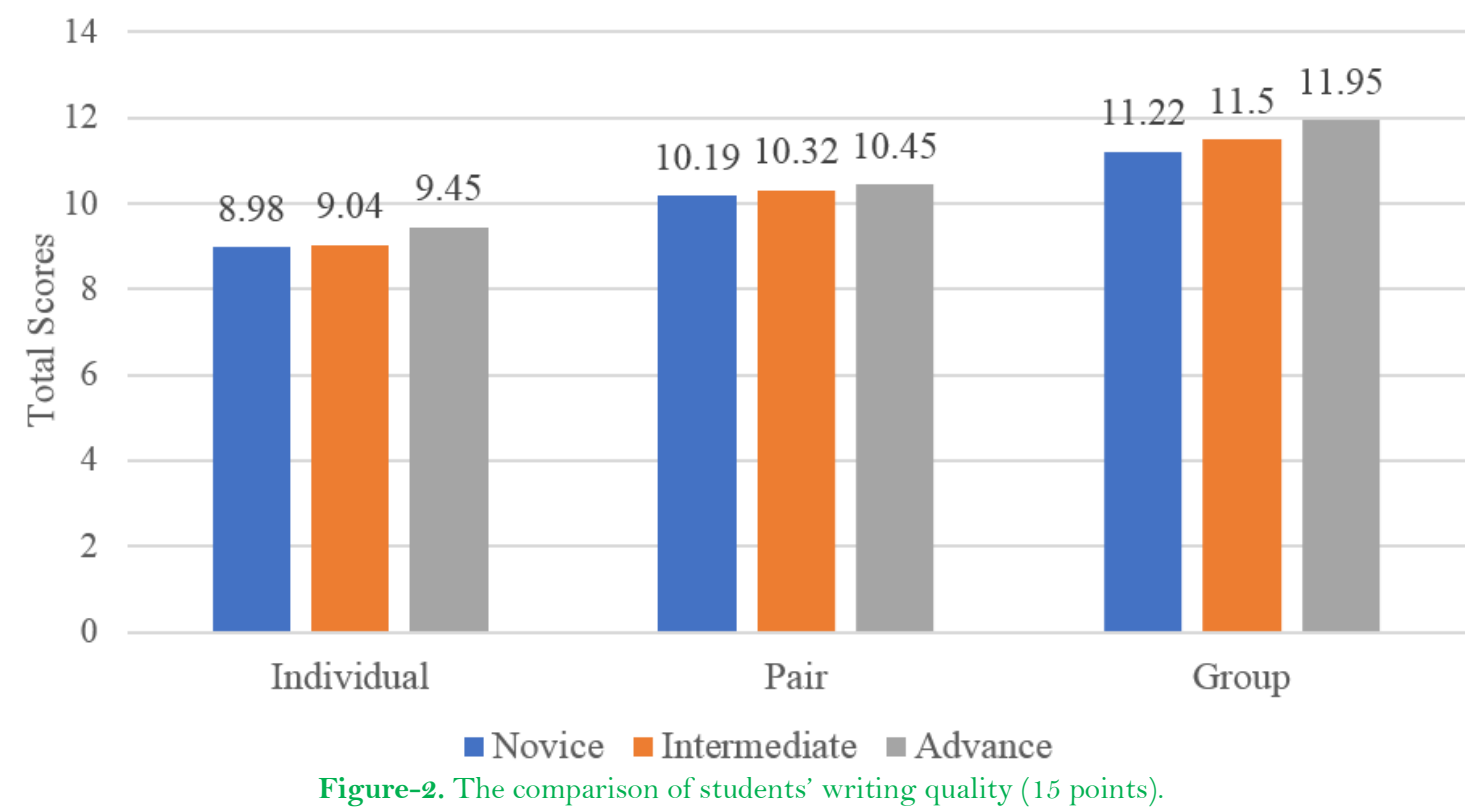

6.2. Research Question 2

What are the students' attitudes towards practicing critical thinking in CW activities (groups of four and pairs) and how did the students implement CW to develop their critical thinking skills?

To reply to the second research question of this study, the semi-structured interview and observation were implemented.

\subsubsection{Semi-Structured Interview}

This section reported the students' critical thinking skills across the different writing activities. The semistructured interviews were conducted in the second phase of the data collection in order to elicit more details of how students perceived different writing activities (individual, pair and group work) towards critical thinking skill practices in a process-based approach writing class. Six students with different English proficiency levels were selected to engage in this interview session. Students $1-2\left(\mathrm{~S}_{1}-\mathrm{S} 2\right)$ were randomly drawn from the novice groups, students 3-4 (S3-S4) from the intermediate groups, and students $5-6(\mathrm{~S} 5-\mathrm{S} 6)$ from the advanced groups. In order to collect this qualitative data, the following question was asked.

- What are your attitudes towards practicing critical thinking skills in the individual, pair, group of four writing activities?

In the interview process, the students' answers were translated into English using the questions in Thai. The following comments present the students' attitudes from the semi-structured interview sessions:

Regarding individual writing, all levels of students realized that they did not practice any critical thinking skills. They considered that they did not participate, evaluate, create, and share any ideas or information with partners. Therefore, they said that this kind of activity could not develop any critical thinking skills at all.

In regards to pair writing activities, novice students analyzed information which was shared by friends. During this analysis, intermediate students analyzed all information from their partners. However, they did not evaluate much about information from friends as little information was shared together. Advanced students also considered that they could develop their critical thinking skills in different ways. They analyzed, created and evaluated all information from peers in order to reach a completed paper.

Regarding group activities, all levels of students considered that group writing developed their critical thinking skills in the aspects of analysis, evaluation, and creation. Advanced students evaluated peers' ideas before 
writing them down in a paper. Novice students reported that they analyzed ideas and information from peers in order to gather all information. Similar to intermediate students, they also analyzed and evaluated all information from peers. Since group activities encouraged participation among friends, students created and evaluated all their ideas in order to reach an agreement and finish their paper. The advanced students also realized that their critical thinking skills were improved in the aspects of analysis, synthesis, and evaluation. Therefore, the research data showed that collaboration improved students' critical thinking skills.

\subsubsection{Observation}

This section indicates findings from the classroom observations. Four groups (2 from pair activities and 2 groups from group activities) were randomly selected in order to observe their conversations and behaviors. Group 1-2 were randomly selected from pair activities and group 3-4 were randomly selected from group activities. For each group observed, the teacher kept hand-written field-note documentation of important events as well as the students' behavior and conversation during the CW activities. On some occasions, the teacher moved around the classroom and talked with students about what they were doing during their class hour. Each observation of the data was classified and analyzed by the researcher according to the six learning levels of Revised Bloom's Taxonomy, which are remembering, understanding, applying, analyzing, evaluating, and creating.

Examples of Revised Bloom's Taxonomy (Anderson $\&$ Krathwohl, 2001) implemented in critical thinking

Group 1

Remembering Students defined the definition of technology.

Understanding Students explained the use of conjunctions to their peers.

Applying Students compared and contrasted the use of relative pronouns.

Evaluating Each student evaluated sentences which were brainstormed by their peers after they finished proposing ideas.

Creating Students created phrases and sentences by selecting relative pronouns to be used correctly with sentences.

Group 2

Remembering Students listed the definition of online learning.

Understanding Students explained what occupation is.

Applying

Analyzing

Creating

Evaluation

Students broke information into parts to explore better understanding.

Group 3

Remembering Students listed the benefits of English.

Understanding Students described how to use English to get a job.

Applying $\quad$ Students illustrated jobs in which required English as a tool.

Analyzing Students categorized jobs which people used English in their work.

Evaluating Students evaluated which ideas were not involved in their topic.

Creating Students invented their paragraphs according to ideas shared from friends.

Group 4

Remembering Students memorized the meaning of different relative pronouns and told their friends how to choose and put relative pronouns in front of nouns.

Understanding Students learned what the benefits of English are as a tool for getting a job.

Applying Students gave some examples of vocabulary to fill in the sentences.

Analyzing Students analyzed which pronouns they found incorrectly.

Evaluation Students evaluated the sentences which were not involved in the topic.

Creating Students gathered all the information and wrote their paragraphs.

Findings from the classroom observation data, analyzed by applying six of learning levels of Revised Bloom's Taxonomy (Anderson \& Krathwohl, 2001) can be considered as relevant qualitative data for acknowledging development in students' critical thinking skills through CW.

In short, based on qualitative data, most of the students considered that their critical thinking skills were improved in the pair and group writing activities. Furthermore, it could be summarized that the students in all levels accepted that CW activities developed their critical thinking skills in the aspect of analysis, evaluation, and creation of a written argument. On the other hand, when writing individually, all students said that it did not help them to improve their critical thinking skills as they had no chance to participate, share or discuss ideas with friends. Furthermore, based on classroom observation data, students developed their critical thinking skills through CW using comparing and contrasting, creating or generating, and evaluating or judging which are higher-level critical thinking skills especially in pair and group work activities. Consequently, in order to enhance students' critical thinking skills in writing class, writing teachers should consider different kinds of writing activities that could help students to enhance their critical thinking skills.

\section{Discussion}

From the findings of the present study, the results of this research of argumentative writing quality and critical thinking skills seemed to reveal positive effects. It was obvious that $\mathrm{CW}$ techniques could enhance both the argumentative writing quality and the students' critical thinking skills. The first question addressed in this study involved the argumentative writing quality across different writing activities (groups, pairs, and individual writing) in terms of language use, content, and the organization of ideas in the text produced by the students. The comparative analysis of texts indicated a positive effect for collaboration on argumentative writing quality. The 
findings may be because the CW activities provided an opportunity to share ideas and interactions between the members of the group and the pair. It led to solving the language problems. This was supported by the social theory of Vygotsky (1978) ), emphasizing that learners require each other to learn and to transmit their knowledge. In accordance with the findings of Ghufron and Hawa (2018), the study aimed to find out whether a CW technique was more effective than direct instruction in teaching argumentative writing. The findings illustrated that CW techniques improved argumentative writing ability. Similar to the results of Ka-kan-dee and Kaur (2015) the CW activities were implemented to improve their students' argumentative writing skills. The results also suggested that EFL learners produced effective argumentative essays using effective collaboration.

Regarding the argumentative writing accuracy, the findings were positively illustrated in accordance with the results of Jafari and Ansari (2012) which focused on the group work effectiveness on Iranian EFL learners' writing accuracy in writing argumentatively. The results emphasized the significant role of collaborative writing, especially in argumentative writing accuracy.

Furthermore, the second research question addressed in the present study involved the students' attitudes in all levels towards critical thinking skills practicing across different writing activities (groups of four, pairs, and individual work) and how the students used CW to enhance their higher-order thinking skills. The students asserted that CW activities could develop their critical thinking skills, while writing individually did not enhance their critical thinking skills. Similar to Ghufron and Hawa (2018), the study also focused on critical thinking skills in $\mathrm{CW}$ activities. The results also revealed that $\mathrm{CW}$ improved critical thinking skills. Moreover, the findings of the present study illustrated that CW activities enhanced the students' critical thinking skills in accordance with the Zivkovic (2016) study which also reported that collaboration improved students' critical thinking skills. Regarding the observation results, collaboration implemented in writing activities encouraged the students and resulted in a greater opportunity to reach the high learning levels in Bloom's Taxonomy. Therefore, it could be assumed that CW activities were oriented to high order thinking skills.

\section{Conclusions}

The results of this study showed that CW activities exerted a positive effect and improved the students' writing quality and their critical thinking skills in all proficiency levels. Therefore, CW activities should be implemented in the writing classroom since they could be an effective strategy for teaching writing in order to develop higher writing quality and critical thinking skills in the students' essays. Regarding the limitations, this study aimed at investigating the students' writing quality across different written activities in regard to only one genre of writing (argumentative writing) and was limited to only thirty-two Thai university students in a northern Thai province. Therefore, the findings were not generalizable to other contexts.

\section{References}

Anderson, L. W. (2001). Objectives, evaluation, and the improvement of education. Studies in Educational Evaluation, 31(2-3), 102-113. Available at: https://doi.org/10.1016/j.stueduc.2005.05.004.

Anderson, L. W., \& Krathwohl, D. R. (2001). A taxonomy for learning, teaching, and assessing. Boston: Allyn and Bacon.

Behar-Horenstein, L., \& Niu, L. (2011). Teaching critical thinking skills in higher education: A review of the literature. Journal of College Teaching and Learning, 8(2), 25-41. Available at: https://doi.org/10.19030/tlc.v8i2.3554.

Chen, W., Elchert, D., \& Garmager, A. (2018). Comparing the effects of teacher collaboration on student performance in Taiwan, Hong Kong and Singapore. Compare: A Journal of Comparative and International Education, 50(4), 515-532. Available at: https://doi.org/10.1080/03057925.2018.1528863.

Chen, W., \& Yu, S. (2019). A longitudinal case study of changes in students' attitudes, participation, and learning in collaborative writing. System, 82, 83-96. Available at: https://doi.org/10.1016/j.system.2019.03.005.

Dobao, A. F. (2012). Collaborative writing tasks in the L2 classroom: Comparing group, pair, and individual work. Journal of Second Language Writing, 21(1), 40-58. Available at: https://doi.org/10.1016/j.jslw.2011.12.002.

Dobao, A. F., \& Blum, A. (2013). Collaborative writing in pairs and small groups: Learners' attitudes and perceptions. System, 41(2), 365-378. Available at: https://doi.org/10.1016/j.system.2013.02.002.

Donato, R. (1994). Collective scaffolding in second language learning, in Vygotskian Approaches to Second Language Research, (Eds.) Lantolf and G. Appel) (pp. 33-56). Ablex: Norwood, NJ.

Dunkel-Schetter, C., \& Bennett, T. L. (1990). Differentiating the cognitive and behavioural aspects of social support. In B. R. Sarason, I. G. Sarason \& G. R. Pierce (Eds.), Social support: An Interactional view (pp. 267-296). New York: John Willey \& Sons.

Ghufron, M., \& Hawa, M. (2018). Teaching writing of argumentative essay using collaborative writing technique viewed from students' creativity: An experimental. Prosiding Ictte Fkip Uns, 1, 25024124.

Hanjani, A. M., \& Li, L. (2014). Exploring L2 writers' collaborative revision interactions and their writing performance. System, 44(9), 101114. Available at: https://doi.org/10.1016/j.system.2014.03.004.

Hirvela, A. (2013). Preparing English language learners for argumentative writing. In L. C. de Oliveria \& T. J. Silva (Eds.), L2 writing in secondary classrooms: Student experiences, academic issues, and teacher education (pp. 67-86). New York: Routledge.

Jafari, N., \& Ansari, D. N. (2012). The effect of collaboration on Iranian EFL learners' writing accuracy. International Education Studies, 5(2), $125-131$.

Ka-kan-dee, M., \& Kaur, S. (2015). Teaching strategies used by Thai EFL lecturers to teach argumentative writing. Procedia-Social and Behavioral Sciences, 208(18), 143-156. Available at: https://doi.org/10.1016/j.sbspro.2015.11.191.

Kaweera, C. (2013). Collaborative writing: A comparative study from EFL students' perspectives. Paper presented at the 7 th International Academic Research Conference on "Sustainable Local Development towards ASEAN Community, 70-85, Thailand: Uttaradit Rajabhat University

Kaweera, C., Yawiloeng, R., \& Tachom, K. (2019). Individual, pair and group writing ctivity: A case study of undergraduate EFL student writing. English Language Teaching, 12(10), 1-13. Available at: https://doi.org/10.5539/elt.v12n 10p1.

Kuhn, D. (1991). The skills of argument. Cambridge UK: Cambridge University Press.

Li, M., \& Kim, D. (2016). One wiki, two groups: dynamic interactions across ESL collaborative writing tasks. Journal of Second Language Writing, 31, 25-42. Available at: https://doi.org/10.1016/j.jslw.2016.01.002.

Li, M., \& Zhu, W. (2017). Good or bad collaborative wiki writing: exploring links between group interactions and writing products. Journal of Second Language Writing, 35(2), 38-53. Available at: https://doi.org/10.1016/j.jslw.2017.01.003.

Liu, O., Shaw, A., Gu, L., \& Li, G. (2018). Assessing college critical thinking: preliminary results from the Chinese HEIghten ${ }^{\circledR}$ Critical Thinking assessment. Higher Education Research and Development, 37(5), 999-1014. Available at: https://doi.org/10.1080/07294360.2018.1467381.

Lukomskaya, L. (2015). Using mentor texts to teach argumentative writing through writing conferences. Education and Human Development Master's Theses, 553. Brockport: State University of New York.

McDonough, K. (2004). Learner-learner interaction during pair and small group activities in a Thai EFL context. System, 32(2), 207-224. Available at: https://doi.org/10.1016/j.system.2004.01.003. 
McDonough, K., \& De Vleeschauwer, J. (2019). Comparing the effect of collaborative and individual prewriting on EFL learners' writing development. Journal of Second Language Writing, 44, 123-130. Available at: https://doi.org/10.1016/j.jslw.2019.04.003.

McDonough, K., Crawford, B., \& De Vleeschauwer, J. (2016). Thai EFL learners' interaction during collaborative writing tasks and its relationship to text quality. In M. Sato \& S. Ballinger (Eds.). Peer Interaction and second language learning: pedagogical potential and research agenda (pp. 185-208). Amsterdam: John Benjamins.

Morris, J. A., Miller, B. W., Anderson, R. C., Nguyen-Jahiel, K. T., Lin, T.-J., Scott, T., . . Ma, S. (2018). Instructional discourse and argumentative writing. International Journal of Educational Research, 90, 234-247.

Neumann, H., \& McDonough, K. (2015). Exploring student interaction during collaborative prewriting discussions and its relationship to L2 writing. Journal of Second Language Writing, 27, 84-104. Available at: https://doi.org/10.1016/j.jslw.2014.09.009.

Paul, R. (1989). Regarding a definition of critical thinking. Paper presented at the International Conference on Critical Thinking and Educational Reform's 25th, Conference, Rohnert Park,CA

Raimes, A. (1983). Techniques in teaching writing. Oxford: Oxford University Press.

Roberson, A. P. (2014). Patterns of interaction in peer response: The relationship between pair dynamics and revision outcomes. Applied Linguistics and English as a Second Language Dissertations. Georgia: Georgia State University.

Shehadeh, A. (2011). Effects and student perceptions of collaborative writing in L2. Journal of Second Language Writing, 20(4), 286-305. Available at: https://doi.org/10.1016/j.jslw.2011.05.010.

Storch, N. (2005). Collaborative writing: Product, process, and students' reflections. Journal of Second Language Writing, 14(3), 153-173. Available at: https://doi.org/10.1016/j.jslw.2005.05.002.

Storch, N. (2013). Collaborative writing in L2 classrooms. Bristol: Multilingual Matters.

Swain, M. (2000). The output hypothesis and beyond: mediating acquisition through collaborative dialogue. In J. P. Lantolf(Ed.), Sociocultural theory and second language learning. Oxford: Oxford University Press.

Swain, M., \& Lapkin, S. (2001). Focus on form through collaborative dialogue: Exploring task effects (pp. 99-1 18). London: Longman.

Vygotsky, L. S. (1978). Mind is society: The development of higher psychological processes. Cambridge: Harvard University Press.

White, R., \& Arndt, V. (1991). Process writing. New York: Longman.

Wiersma, W. (1995). Research methods in education: An introduction. Boston: Allyn and Bacon.

Woo, E. (1999). Obituary: Benjamin S. Bloom, education scholar's research influenced head start program. Los Angeles: Times.

Wu, S. M., \& Allison, D. (2005). Evaluative expressions in analytical arguments: Aspects of appraisal in assigned English language essays. Journal of Applied Linguistics, 2(1), 105-127. Available at: https://doi.org/10.1558/japl.v2i1.105.

Zhang, M. (2018). Collaborative writing in the EFL classroom: The effects of L1 and L2 use. System, 76(1), 1-12. Available at: https://doi.org/10.1016/j.system.2018.04.009.

Zhang, M. (2019). Towards a quantitative model of understanding the dynamics of collaboration in collaborative writing. Journal of Second Language Writing, 45, 16-30. Available at: https://doi.org/10.1016/j.jslw.2019.04.001.

Zivkovic, S. (2016). A model of critical thinking as an important attribute for success in the 21st century. Paper presented at the International Conference on Teaching and Learning English as an Additional Language, GlobELT. 